\title{
Thermodynamic Properties of Hydrofluoroolefin (R1234yf and R1234ze(E)) Refrigerant Mixtures: Density, Vapour-Liquid Equilibrium, and Heat Capacity Data and Modelling
}

Saif ZS. Al Ghafri, ${ }^{a}$ Darren Rowland, ${ }^{a}$ Masoumeh Akhfash, ${ }^{a}$ Arash Arami Niya, ${ }^{a}$

Martin Khamphasith, ${ }^{\mathrm{a}}$ Xiong Xiao, ${ }^{\mathrm{a}},{ }$ Tomoya Tsuji, ${ }^{\mathrm{b}}$ Yukio Tanaka, ${ }^{\mathrm{c}}$ Yoshio Seiki, ${ }^{\mathrm{d}}$, Eric F. May. Thomas J. Hughes, ${ }^{\text {** }}$

${ }^{\text {a }}$ Fluid Science \& Resources Division, Department of Chemical Engineering, University of Western Australia, Crawley, WA 6009, Australia

b Malaysia-Japan International Institute of Technology, Universiti Teknologi Malaysia, Kuala Lumpur 54100, Malaysia

${ }^{\mathrm{c}}$ Chemical Research Department, Research \& Innovation Center, Mitsubishi Heavy Industries, LTD, Hiroshima, 733-8553, Japan

${ }^{\mathrm{d}}$ Global Research \& Innovation Center, Mitsubishi Heavy Industries Asia Pacific PTE. LTD. Singapore 189720.

e Oil and Gas Engineering, Resources Engineering, Department of Civil Engineering, Monash University, Clayton, VIC 3800, Australia

*corresponding author: Email: tom.hughes@monash.edu, Tel: +61 399054678

Keywords: Hydrofluoroolefins; vapour-liquid equilibrium; density; heat capacity 


\section{Abstract}

Liquid-phase and vapour-phase densities are reported for the binary refrigerant mixtures (R125 + R1234ze(E)), (R134a + R1234ze(E)), (R143a + R1234ze(E)), (R1234ze(E) + R1234yf), (R125 + $\mathrm{R} 1234 \mathrm{yf}),(\mathrm{R} 143 \mathrm{a}+\mathrm{R} 1234 \mathrm{yf})$ and (R125 + R152a). The measurements span temperatures from (252 to 294) $\mathrm{K}$ and pressures from (0.8 to 4.2) MPa. Vapour-liquid equilibria (VLE) and liquid isobaric heat capacities are also reported for some mixtures. These measurements and previously published data were used to tune binary interaction parameters in existing Helmholtz energy models. Significant improvements in the predicted densities were achieved, for example the root mean squared relative deviation decreased from $0.33 \%$ to $0.021 \%$ for (R143a + R1234yf). The most significant improvement in the description of VLE occurred for $(\mathrm{R} 1234 \mathrm{yf}+\mathrm{R} 1234 \mathrm{ze}(\mathrm{E}))$ where the root mean squared deviation in the predicted vapour phase compositions decreased from 0.010 to 0.00084 (a factor of 12). 


\section{Introduction}

Refrigerants containing hydrofluoroolefins (HFOs) are of interest as they could serve as more environmentally-friendly alternatives to chlorofluorocarbons (CFCs) and hydrofluorocarbons (HFCs). For the design and simulation of refrigeration systems using mixtures containing HFOs, accurate knowledge of thermodynamic properties including density, enthalpy, heat capacity and vapour-liquid equilibrium is important. The thermodynamic properties of the pure HFO compounds R1234yf and R1234ze(E) are quite well characterised. However, mixtures containing these HFOs have not been investigated comprehensively as indicated by the data sets listed in Table 1, which were found during a literature survey. From this survey, only the systems (R32 + R1234ze(E)) and $(\mathrm{R} 32+\mathrm{R} 1234 \mathrm{yf})$ have been characterised with extensive measurements for more than one thermodynamic property of interest.

Table 1. Summary of literature sources of thermodynamic property data for binary mixtures containing HFOs R1234yf or R1234ze(E).

\begin{tabular}{|c|c|c|c|}
\hline System & Reference & $N$ & Range $(T, p, z)^{\mathrm{a}}$ \\
\hline R32 + R1234ze(E) & Akasaka, 2011 & 31 (VLE) & $\begin{array}{l}282-292 \mathrm{~K}, 0.4-1.4 \mathrm{MPa} \text {, } \\
0.05-0.95\end{array}$ \\
\hline R32 + R1234ze(E) & $\begin{array}{l}\text { Tanaka et al., } \\
2011\end{array}$ & $40(\rho), 48\left(c_{p}\right)$ & $\begin{array}{l}310-350 \mathrm{~K} ; 1.5-5 \mathrm{MPa} ; \\
0.43-0.67\end{array}$ \\
\hline $\mathrm{R} 32+\mathrm{R} 1234 \mathrm{ze}(\mathrm{E})$ & Jia et al., 2016 & $416(\rho)$ & $\begin{array}{l}283-363 \mathrm{~K} ; 3-100 \mathrm{MPa} \\
0.17-0.94\end{array}$ \\
\hline R32 + R1234ze(E) & $\begin{array}{l}\text { Kobayashi et al., } \\
2011\end{array}$ & $125(\rho)$ & $\begin{array}{l}361-400 \mathrm{~K} ; 3.4-7.0 \mathrm{MPa} \\
0.42-0.69\end{array}$ \\
\hline R134a + R1234ze(E) & Zhang et al., 2017 & $101(\rho)$ & $\begin{array}{l}270-300 \mathrm{~K} ; 0.1-0.5 \mathrm{MPa} \\
0.43-0.64\end{array}$ \\
\hline $\mathrm{R} 134 \mathrm{a}+\mathrm{R} 1234 \mathrm{ze}(\mathrm{E})$ & Raabe, 2014 & 3 (VLE) & $\begin{array}{l}273-313 \mathrm{~K} ; 0.3-0.9 \mathrm{MPa} \\
0.24-0.31\end{array}$ \\
\hline R1234yf + R1234ze(E) & Higashi, 2016 & $38(\rho)$ & $\begin{array}{l}340-430 \mathrm{~K} ; 1.7-6.7 \mathrm{MPa} \text {; } \\
0.5\end{array}$ \\
\hline $\mathrm{R} 32+\mathrm{R} 1234 \mathrm{yf}$ & $\begin{array}{l}\text { Kamiaka et al., } \\
2013\end{array}$ & 63 (VLE) & $\begin{array}{l}273-333 \mathrm{~K}, 0.5-3.3 \mathrm{MPa}, \\
0.34-0.84\end{array}$ \\
\hline $\mathrm{R} 32+\mathrm{R} 1234 \mathrm{yf}$ & Hu et al., 2017 & 45 (VLE) & $\begin{array}{l}283-323 \mathrm{~K} ; 0.5-2.8 \mathrm{MPa} \\
0.08-0.80\end{array}$ \\
\hline $\mathrm{R} 32+\mathrm{R} 1234 \mathrm{yf}$ & Dang et al., 2015 & $26(\rho)$ & $\begin{array}{l}283-320 \mathrm{~K} ; 2.2-3.0 \mathrm{MPa} \\
0.48-0.84\end{array}$ \\
\hline $\mathrm{R} 32+\mathrm{R} 1234 \mathrm{yf}$ & $\begin{array}{l}\text { Akasaka et al., } \\
2013\end{array}$ & $40(\rho)$ & $340-363 \mathrm{~K} ; p^{\text {sat}} ; 0.20-0.69$ \\
\hline $\mathrm{R} 32+\mathrm{R} 1234 \mathrm{yf}$ & Raabe, 2014 & $12(\rho)$ & $\begin{array}{l}273-313 \mathrm{~K} ; 1.0-3.5 \mathrm{MPa} ; \\
0.2-0.8\end{array}$ \\
\hline R125 + R1234yf & $\begin{array}{l}\text { Kamiaka et al., } \\
2013\end{array}$ & 56 (VLE) & $\begin{array}{l}273-333 \mathrm{~K} ; 0.4-2.3 \mathrm{MPa} \\
0.19-0.49\end{array}$ \\
\hline R143a + R1234yf & Hu et al., 2013 & 35 (VLE) & $\begin{array}{l}283-323 \mathrm{~K} ; 0.5-2.1 \mathrm{MPa} \\
0.08-0.84\end{array}$ \\
\hline
\end{tabular}

${ }^{\mathrm{a}} z$ is the mole fraction composition of the first-named component in the binary mixture.

The chief motivations for the present work were to broaden the coverage of experimental data for key binary refrigerant mixtures of HFOs and HFCs and to tune thermodynamic models to improve the prediction of mixture properties. New measurements for liquid density, vapour density, liquid isobaric heat capacity, and vapour-liquid equilibrium (VLE) are reported. Thermodynamic models based on 
Helmholtz equations of state (EOS) are tuned to match the new experimental data and the available literature data (Table 1). Liquid heat capacities of pure HFOs R1234yf and R1234ze(E) in the temperature range (283 to 303 ) $\mathrm{K}$ are also measured, the latter being for the first time.

\section{Material and Methods}

\subsection{Materials}

The refrigerants investigated in this study are given in Table 2.

Table 2. Refrigerants studied in this work, chemical supplier and purity

\begin{tabular}{ccccc}
\hline $\begin{array}{c}\text { ASHRAE } \\
\text { Refrigerant } \\
\text { Number }\end{array}$ & IUPAC name & CAS \# & Supplier & $\begin{array}{c}\text { Supplier } \\
\text { Purity }^{\mathrm{c}}\end{array}$ \\
\hline 32 & Difluoromethane $^{\mathrm{a}}$ & $75-10-5$ & Core Gas & 0.995 \\
125 & Pentafluoroethane $^{\mathrm{a}}$ & $354-33-6$ & Core Gas & 0.995 \\
$134 \mathrm{a}$ & $1,1,1,2-$ Tetrafluoroethane $^{\mathrm{a}}$ & $811-97-2$ & Core Gas & 0.995 \\
$143 \mathrm{a}$ & $1,1,1-$ Trifluoroethane $^{\mathrm{a}}$ & $420-46-2$ & Core Gas & 0.995 \\
$152 \mathrm{a}$ & $1,1-$ Difluoroethane $^{\mathrm{a}}$ & $75-37-6$ & Core Gas & 0.995 \\
$1234 \mathrm{yf}$ & $2,3,3,3-$ Tetrafluoropropene $^{\mathrm{b}}$ & $754-12-1$ & Core Gas & 0.995 \\
$1234 \mathrm{ze}(\mathrm{E})$ & $\begin{array}{c}\text { (E)-1,3,3,3- } \\
\text { Tetrafluoropropene }^{\mathrm{b}}\end{array}$ & $29118-24-9$ & Core Gas & 0.995 \\
\hline
\end{tabular}

${ }^{\mathrm{a}} \mathrm{HFC}$ compound ${ }^{\mathrm{b}} \mathrm{HFO}$ compound ${ }^{\mathrm{c}}$ mole fraction basis

Different procedures for preparing and loading the refrigerant mixtures were used depending on the experimental apparatus. For the density measurements, where only single-phase properties were measured, synthetic binary mixtures were prepared via the following steps using three high pressure syringe (ISCO) pumps in an arrangement shown in Fig. 1.

1. Prior to loading, the pumps were flushed with nitrogen and subsequently evacuated using a vacuum pump attached to the apparatus. The evacuation process was continued for at least 10 hours whilst the whole system was heated to about $333 \mathrm{~K}$ to eliminate the presence of any air or contaminants. This cleaning cycle (evacuation followed by subsequent flushing) was performed at least three times to decrease the level of impurities or air to a minimum.

2. Each single-component refrigerant was loaded into a separate syringe pump from their respective refrigerant cylinder. At least $250 \mathrm{~cm}^{3}$ of the pure refrigerant was loaded in a liquid phase at ambient temperature and compressed to around $5 \mathrm{MPa}$, which was significantly higher than their saturation pressures.

3. These two syringe pumps were then connected to a third syringe pump equipped with an in-built, magnetically-driven stirrer capable of operating at high pressure. The two refrigerants were injected sequentially at a rate of about $1 \mathrm{~mL} \cdot \mathrm{min}^{-1}$ under a constant pressure above $5 \mathrm{MPa}$. This was done by placing the mixing syringe pump (Pump 3) in constant pressure mode as the pure refrigerant from either Pump 1 or 2 was injected at the specified rate. The volume injected was recorded and used to calculate the number of moles of the component refrigerant loaded into the third syringe pump using the 
appropriate reference equation of state implemented in REFPROP 9.1 (Lemmon et al., 2013).

4. The in-built magnetically-driven stirrer in the third syringe was then operated at $1000 \mathrm{rpm}$ for a period of around 12 hours at constant pressure (5 MPa) to homogenise the mixture. The syringe pump containing the pressurised, homogenised liquid mixture was then isolated from the other pumps and connected to the apparatus (densimeter) into which it was to be loaded.

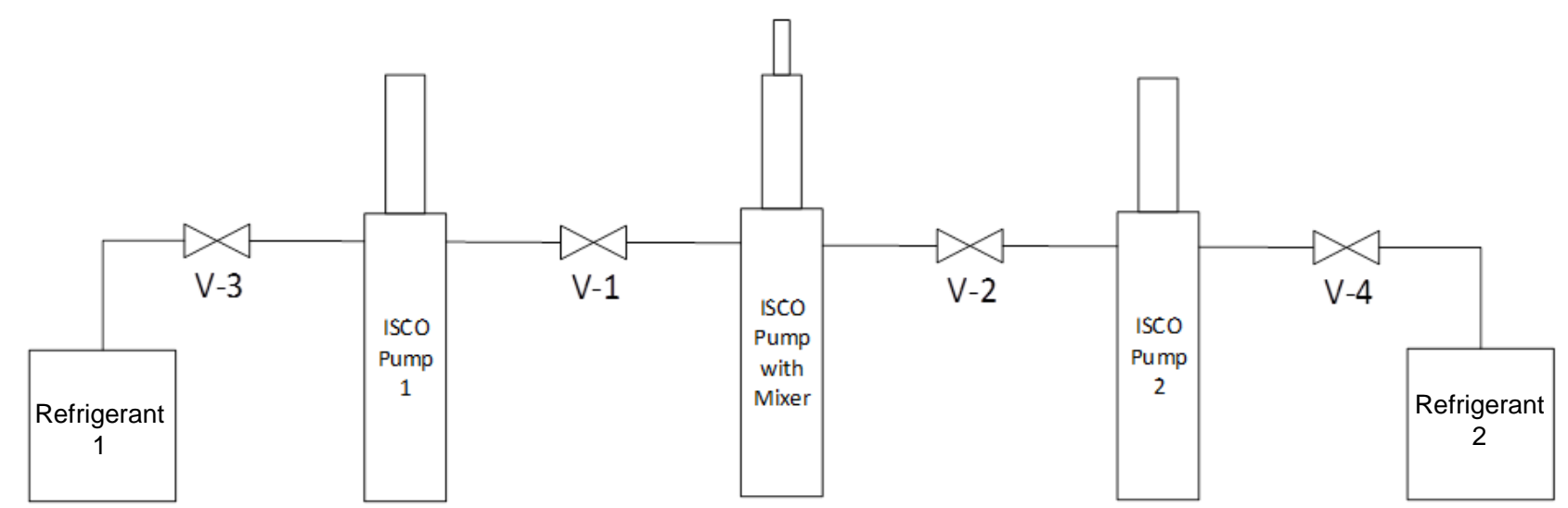

Fig. 1. Schematic diagram of the system used for preparing homogenous liquid refrigerant mixtures.

The combined standard uncertainty of a component mole fraction $\left(x_{1}\right)$ is given by:

$$
u^{2}\left(x_{1}\right)=\left[n_{1}\left(\frac{\partial x_{1}}{\partial n_{1}}\right) u_{r}\left(n_{1}\right)\right]^{2}+\left[n_{2}\left(\frac{\partial x_{1}}{\partial n_{2}}\right) u_{r}\left(n_{2}\right)\right]^{2}
$$

Here $n_{1}$ and $n_{2}$ corresponds to the injected number of moles of component 1 and 2 , respectively; $u_{\mathrm{r}}$ is the standard relative uncertainty of the molar amount, which is related to the standard relative uncertainties of the molar densities and injected volumes. Thus, the overall combined standard uncertainty in the measured synthetic mole fraction of a component is mainly affected by uncertainty in the volume expelled from the syringe pumps and the fluid density under the pump conditions. The uncertainty of the fluid density is affected by the uncertainties of pressure, temperature, and the equation of state from which the density is calculated. The standard relative uncertainty of the pump volumes was found to be $0.1 \%$ for both syringe pumps. Taking this into account, and considering mixture homogeneousity and uncertainties associated with mixture transfer, the standard uncertainty in the mole fraction of the prepared mixtures were taken as $u(x)=0.01$, for all the binary mixtures prepared in this work.

\subsection{Density method}

The densities of the binary refrigerant mixtures were measured with a commercial, high-pressure vibrating tube densimeter (VTD, Anton Paar, DMA HPM). A schematic diagram of the apparatus is shown in Fig. 2. The VTD is designed to measure the density of liquids and gases at pressures up to $140 \mathrm{MPa}$ and temperatures up to $473 \mathrm{~K}$ using a U-shaped vibrating tube of $2 \mathrm{~mL}$ total volume. A high pressure ISCO syringe pump was connected to the VTD and used to inject the mixture and control the pressure. The temperature of the VTD was controlled by the circulation of hot (silicone oil) or cold (ethanol) thermostatting fluids. The pressure and temperature were measured with a 
calibrated pressure transducer (Keller, PA-33X) and a platinum resistance thermometer located in the cellblock, respectively. The overall standard uncertainty of the cell temperature was estimated to be $0.1 \mathrm{~K}$, taking into account temperature gradient and fluctuation. The pressure transducer was calibrated in situ by comparison with a reference quartz-crystal pressure transducer (Parascientific Digiquartz series 1000) with a full scale of $14 \mathrm{MPa}$ and a relative uncertainty of $0.008 \%$ of full scale as stated by the manufacturer. The standard deviation of the transducer's calibration was estimated to be $0.02 \mathrm{MPa}$ for the entire pressure range considered in the present work.

The VTD was connected to a system controller (Anton Paar, Davis5) which displayed the measured parameters including the pressure, temperature and the tube's resonant period of oscillation $(\tau)$. These quantities were used to calculate the fluid density $\left(\rho_{\mathrm{F}}\right)$ according to the model described by May et al. (2014).

$$
\rho_{F}=\frac{\left(\rho_{M} / S_{00}\right)}{\left(1+\alpha_{V} t+\beta_{V} p\right)} \times\left(\left(\frac{\tau}{\tau_{00}\left(1+\varepsilon_{\tau 1} t+\varepsilon_{\tau 2} t^{2}\right.}\right)^{2}\left(1+\beta_{\tau} p\right)-1\right)
$$

Here $S_{00}$ is the geometric sensitivity factor of evacuated tube at reference temperature; $\tau_{00}$ is resonance period of evacuated tube at reference temperature; $\varepsilon_{\tau 1}$ and $\varepsilon_{\tau 2}$ are the linear and quadratic temperature response coefficients of spring constant respectively; $\beta_{\tau}$ is the pressure response coefficient of spring constant; $\alpha_{\mathrm{V}}$ and $\beta_{\mathrm{V}}$ are the linear temperature response and pressure response coefficients of tube volume respectively. Detailed description of the seven apparatus parameters used in this model and how they might be determined is previously described by May et al. (2014).

Calibrations of the VTD were performed using water and helium as reference substances (see Supplementary Material). The measured periods were reproducible within $0.02 \mu$ s. Taking into account measurements reproducibility, calibration accuracy, pressure, temperature and mixture composition uncertainties, the overall combined standard relative uncertainties of densities were found to spans between (0.05 and 0.1$) \%$ and (0.6 and 1) \% for liquid and vapor measurements respectively. For the sake of simplicity, we ascribe the value of $0.1 \%$ and $1 \%$ to the combined standard relative uncertainty in the liquid and vapor density measurements. (See Supplementary Material for more details).

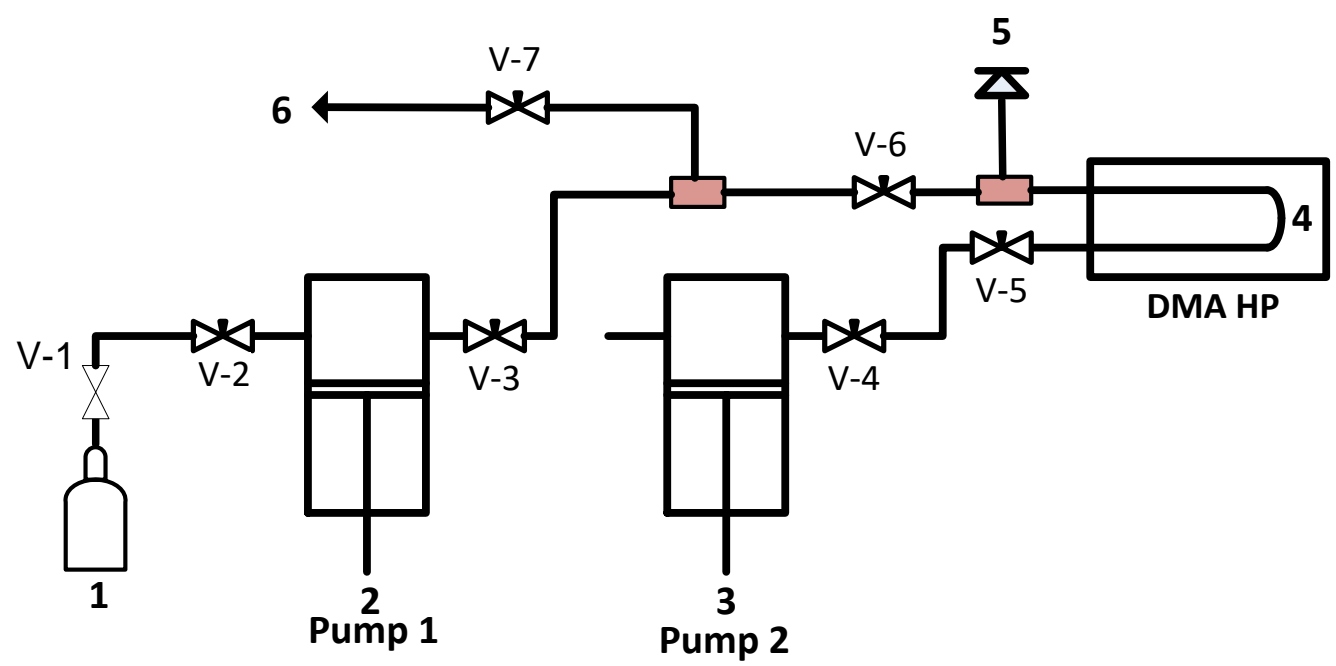

Fig. 2. Schematic diagram of the VTD assembly. (1), pure refrigerant bottle, (2,3) syringe pumps, (4) vibrating tube densimeter, (5) pressure transducer, (6) waste/vacuum. 
Prior to loading each binary mixture, the densimeter was flushed many times, evacuated and then pressurized with one of the mixture's pure refrigerant components to above the mixture's saturation pressure using pump 1 up to valve V-4 (Fig. 2). To displace the mixture through the VTD and avoid phase change or fractionation, pump 1 was placed in constant pressure mode, pump 2 (which contained the synthetically-prepared mixture) was set to constant flow mode at a low flow rate (2 $\mathrm{ml} \cdot \mathrm{min}^{-1}$ or less), and valve V-4 was opened. The displacement continued until at least three times the volume of the VTD $(\approx 2 \mathrm{ml})$ had passed through the cell. Once the displacement process was complete, valve V-6 was closed and pump 2 was set to constant pressure mode at the desired pressure for a few hours. Then valve V-5 was closed and the mixture inside the VTD was left to stabilize for another few hours before the measurement was recorded.

\subsection{Vapour-liquid equilibrium method}

Measurements of VLE were completed via the analytic method (sampling and gas chromatography) with the apparatus shown in Fig. 3 This apparatus is very similar to those described previously for measurements of systems relevant to natural gas processing (Kandil et al., 2010; Kandil et al., 2011; Hughes et al., 2014; Hughes et al., 2015; May et al., 2015; Hughes et al., 2017). The major difference in this apparatus from those described previously was the placement of the equilibrium cell inside an incubator oven (Memmert IPP 110) rather than inside a vacuum can within a Dewar. This incubator oven with Peltier cooling can be equilibrated at temperatures between (273.15 and 343.15) K in contrast to our previously described apparatus which is designed for operation below room temperature only.

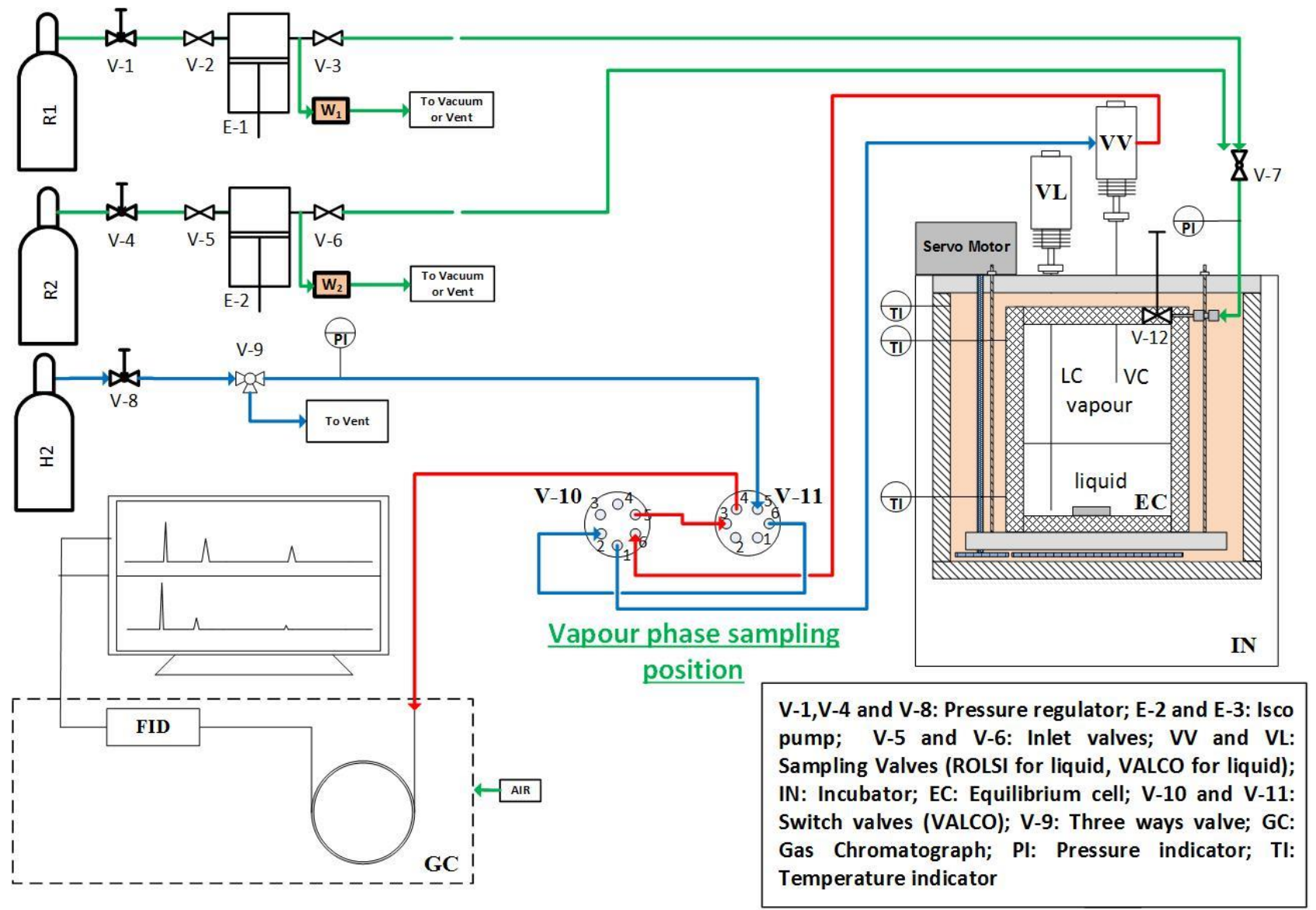

Fig. 3. Schematic of the VLE apparatus. 
For VLE measurements, the mixtures were prepared by the direct injection of the pure refrigerant liquids into the equilibrium cell so that the liquid volume fraction of the two-phase mixture at ambient temperature would be approximately $60 \%$. Once the two refrigerants were injected, the VLE cell was isolated, heated to $413 \mathrm{~K}$ (well above the mixture critical point or cricondentherm temperature) and mixed with a magnetic stirrer to achieve homogeneity. After equilibration at the target temperature, vapour and liquid compositions were analyzed by a gas chromatograph (GC) (Agilent 7890A) equipped with a capillary column (Agilent GS GasPro) and a flame ionization detector (FID). To avoid saturation of the GC column or its detector, and to minimize disturbance of the phase equilibrium inside the cell, specialized sampling valves were used for both the liquid and vapour phases. The liquid phase was sampled via a capillary tube (internal diameter less than $0.15 \mathrm{~mm}$ ) coupled with "Rapid On-Line Sampler Injector" (ROLSI) electromagnetic solenoid valve. The vapour phase was sampled by a rapid switching valve (Valco). The GC calibration procedure is described in the Supplementary Material.

The cell's temperature was controlled by the incubator to within $\pm 0.1 \mathrm{~K}$. Several hours were allowed to establish equilibrium, which was identified when the pressure reached a constant value. The compositions of both phases at each experimental point were sampled several times to determine the uncertainty contribution associated with sampling and/or GC analysis.

In this work, two PRT's sensors (NR-141-100S, Nitsushin) mounted on the top and bottom of the cell were used to measure temperature, with standard uncertainty of the cell temperature estimated to be $0.1 \mathrm{~K}$. The system pressure was recorded using a quartz-crystal pressure transducer (Digiquartz, Parascientific), with a standard uncertainty of $0.02 \mathrm{MPa}$. The overall combined standard uncertainties of mole fraction vary over a wide range depending upon the component, temperature, pressure, and phase in question, as presented in table 4. The uncertainty calculations is described in the Supplementary Material.

\subsection{Isobaric heat capacity method}

Isobaric heat capacities, $c_{p}$, of liquid mixtures were measured using a specialised differential scanning calorimeter (DSC) as shown in Fig. 4. This instrument has previously been used for measurements of heat capacities, enthalpies of phase transitions and phase transition temperatures (Hughes et al., 2011; Syed et al., 2012; Syed et al., 2014; Oakley et al., 2017; Syed et al., 2017). The calibration of the DSC's heat flux sensor is discussed by Hughes et al. (2011) and temperature calibration was most recently described by Oakley et al. (2017). The apparatus was modified for these measurements. A water circuit utilising a temperature-controlled water bath replaced the use of liquid nitrogen to cool the instrument. At the temperatures concerned (within $30 \mathrm{~K}$ of room temperature) this provided more stable calorimetric signals compared to using liquid nitrogen cooling. The temperature-controlled water bath was set to be $3 \mathrm{~K}$ lower than the DSC temperature and was controlled to follow the temperature profile during scanning with a $-3 \mathrm{~K}$ offset. This minimised the heating required for the stem and, because liquid nitrogen was not being used, no cold spot part-way up the stem was present as was observed previously (Syed et al., 2012).

Liquid mixtures were prepared using the apparatus shown in Fig. 4. To make a mixture, the refrigerant cylinder containing the first component was connected to the system at valve 9 . The system and cell were evacuated and flushed at least three times to remove air and impurities. Refrigerant was then drawn as a liquid into the ISCO 260D syringe pump (pump 1) and the pure refrigerant was pressurised to $2 \mathrm{MPa}$ in the pump. Valves 5 and 6 were then gently opened, so that pump 1 could maintain constant pressure, to slowly fill the FloXlab BTSP-500-5 syringe pump (pump 2) which contains an inbuilt mixer. The amount of refrigerant metered into pump 2 was calculated from the volume change in pump 1 and the density of the pure refrigerant calculated using its reference equation of state as 
implemented in the software REFPROP 9.1 (Lemmon et al., 2013). Pump 1 and the system excluding pump 2 were then depressurised, evacuated and flushed several times before the cylinder containing the second refrigerant component was connected to the system at valve 9 . The second component was added into pump 2 by the same method used for the first component. The mixture inside pump 2 was homogenised using the inbuilt mixer. The remaining pure second component in pump 1 was then used to backfill the DSC measurement cell (up to valve 4) to a pressure of $2 \mathrm{MPa}$. The DSC cell is connected with a $1.59 \mathrm{~mm}$ (outside diameter) capillary running close to the bottom of the cell. This capillary is concentric to a larger tube ( $3 \mathrm{~mm}$ internal diameter) connected to the top of the DSC cell. To flush the mixture through the cell, pump 1 was set to maintain constant pressure ( $2 \mathrm{MPa})$. Then pump 2 was then set to constant flow mode at a low flow rate $\left(2 \mathrm{ml} \cdot \mathrm{min}^{-1}\right.$ or less $)$ and valve 4 was simultaneously opened. This ensured displacement of the mixture through the DSC cell without any inadvertent phase change thereby avoiding fractionation of the mixture. The displacement continued until at least three times the volume of the DSC cell $(\approx 9 \mathrm{ml})$ had passed through the cell. Once the displacement process was complete, valve 2 was closed and pump 2 was set to constant pressure mode at the desired pressure of the measurement.

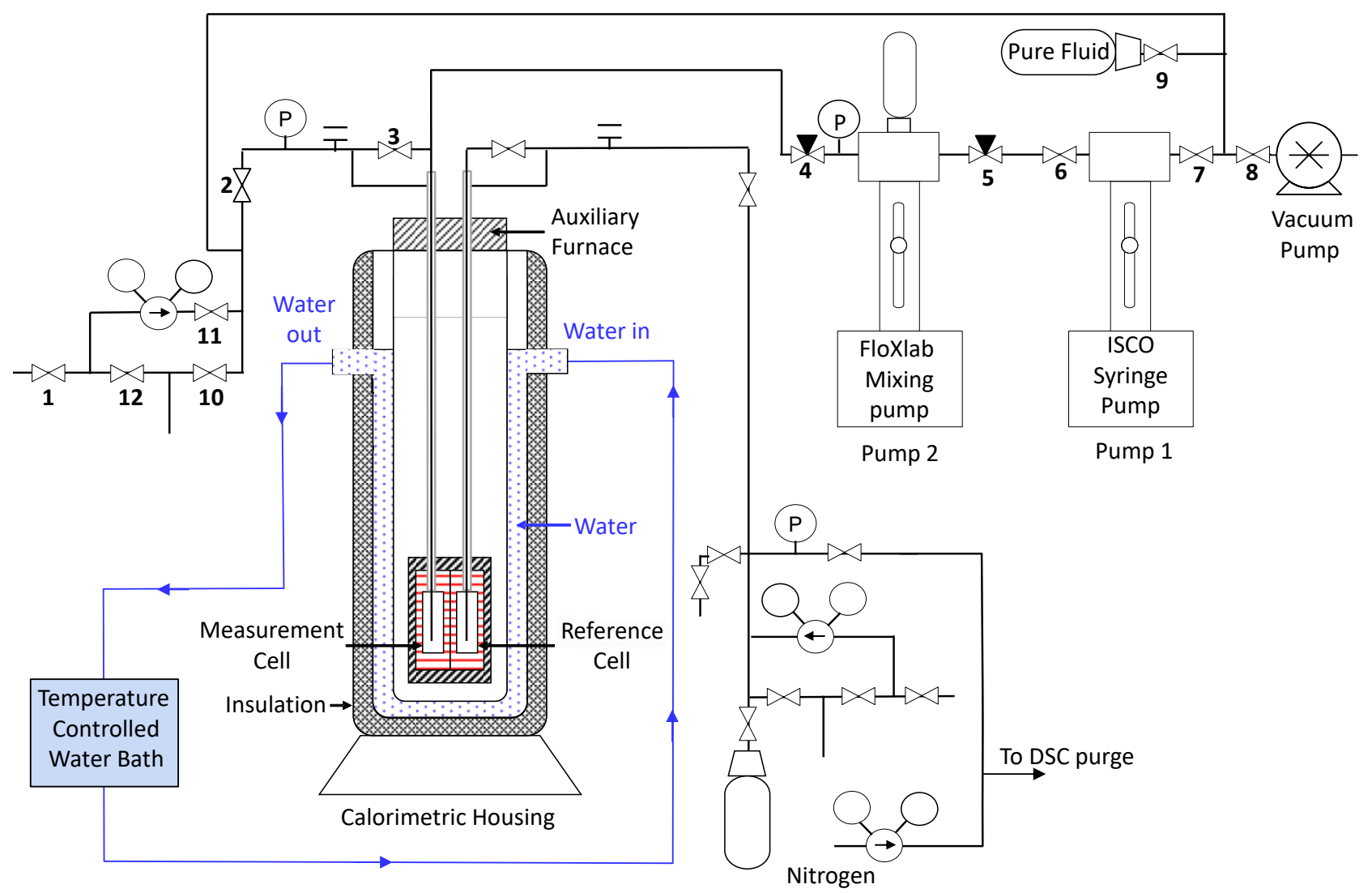

Fig. 4. Differential scanning calorimeter used for measurements of the isobaric heat capacities of liquid refrigerant mixtures.

The isobaric heat capacity was measured by the step method with the DSC's reference cell filled with dry nitrogen at atmospheric pressure. Following an initial isothermal equilibration period of $4 \mathrm{~h}$ the DSC furnace temperature was increased by $10 \mathrm{~K}$ at a constant rate of $0.15 \mathrm{~K} \cdot \mathrm{min}^{-1}$. A final isothermal period of $6 \mathrm{~h}$ followed the temperature ramp. To account for the heat capacity of the DSC cell itself, a series of blank experiments with dry nitrogen gas under atmospheric pressure in the measurement cell were also performed. The isobaric heat capacities were then calculated from 


$$
c_{p}=\frac{\int \Phi_{\mathrm{s}} \mathrm{d} t-\int \Phi_{\mathrm{b}} \mathrm{d} t}{\rho V_{\text {cell }} \Delta T_{\text {step }}}
$$

where $\int \Phi_{\mathrm{s}} \mathrm{d} t$ is the integrated heat flow difference between the measurement cell filled with sample and the reference cell containing dry $\mathrm{N}_{2}$ at atmospheric pressure over the temperature step (scan), $\int \Phi_{\mathrm{b}} \mathrm{d} t$ is the integrated heat flow difference for the calibration scans where both the measurement and reference cells were filled with dry $\mathrm{N}_{2}, \rho$ is the fluid density, $V_{\text {cell }}$ is the volume of the cell and $\Delta T_{\text {step }}$ is the temperature step $(10 \mathrm{~K})$. The volume of the cell was determined to be $(8.947 \pm 0.024) \mathrm{cm}^{3}$ using propane at a pressure of $3 \mathrm{MPa}$ as a reference fluid. Mixtures densities $(\rho)$ were obtained using default Helmholtz energy mixture model implemented in REEFPROP 9.1.

Contributions to the combined standard uncertainty in the measured heat capacity were estimated. (See supplementary material for the details). The variables that mainly contribute to the overall uncertainties in the heat capacity measurements are uncertainties associated with the calibration of heat flow and cell volume. In addition, the effect of the temperature, pressure, density and composition uncertainties on the heat capacity measurements were also considered as contributors to the combined uncertainty. The overall combined standard uncertainties are presented in tables 5 and 6 for every pressure and temperature condition. 


\subsection{Helmholtz energy mixture model}

Helmholtz energy models are widely used as reference equations of state for many pure fluids. The thermodynamic properties of the pure refrigerants studied in this work are described by the reference EOS in Table 3.

Table 3. Refrigerants studied in this work, sources of their pure fluid equations of state in the software REFPROP 9.1 (Lemmon et al., 2013) and expected uncertainties for various properties

\begin{tabular}{|c|c|c|}
\hline $\begin{array}{l}\text { ASHRAE Refrigerant } \\
\text { Number }\end{array}$ & Reference equation of state & Expected uncertainty \\
\hline 32 & $\begin{array}{l}\text { Tillner-Roth and Yokozeki, } \\
1997\end{array}$ & $\begin{array}{c}\rho=0.05 \% \\
p_{\text {sat }}=0.02 \% \\
c_{p, \text { liq }}=0.5-1 \%\end{array}$ \\
\hline 125 & $\begin{array}{l}\text { Lemmon and Jacobsen, } \\
2005\end{array}$ & $\begin{array}{c}\rho=0.04-0.5 \% p_{\text {sat }}=0.2 \% \\
c_{p, \text { liq }}=0.5 \%\end{array}$ \\
\hline $134 \mathrm{a}$ & $\begin{array}{l}\text { Tillner-Roth and Baehr, } \\
1994\end{array}$ & $\begin{array}{c}\rho=0.05 \% \\
p_{\text {sat }}=0.02 \% \\
c_{p, \text { liq }}=0.5-1 \%\end{array}$ \\
\hline $143 \mathrm{a}$ & $\begin{array}{l}\text { Lemmon and Jacobsen, } \\
2000\end{array}$ & $\begin{array}{c}\rho=0.1 \% \\
p_{\text {sat }}=0.02 \% \\
c_{p, \text { liq }}=0.5 \%\end{array}$ \\
\hline $152 \mathrm{a}$ & Outcalt and McLinden, 1996 & $\begin{array}{c}\rho=0.1 \% \\
p_{\text {sat }}=0.1 \% \\
c_{p, \text { liq }}=2 \%\end{array}$ \\
\hline $1234 y f$ & Richter et al., 2011 & $\begin{array}{c}\rho_{\text {vap }}=0.5 \% \\
\rho_{\text {liq }}=0.1 \% \\
p_{\text {sat }}=0.1 \% \\
c_{p, \text { liq }}=5 \%\end{array}$ \\
\hline $1234 z e(E)$ & Thol and Lemmon, 2016 & $\begin{array}{c}\rho_{\text {vap }}=0.5 \% \\
\rho_{\text {liq }}=0.1 \% \\
p_{\text {sat }}=0.1 \%, \\
c_{p, \text { liq }}=5 \%\end{array}$ \\
\hline
\end{tabular}

The mixture model for the Helmholtz energy used in this work utilises the same mixing rules as in GERG-2004 and GERG-2008 EOS (Kunz et al., 2007; Kunz and Wagner, 2012; Rowland et al., 2016), i.e.

$\frac{1}{\rho_{c, i j}}=\beta_{v, i j} \gamma_{v, i j} \frac{x_{i}+x_{j}}{\beta_{v, i j}^{2} x_{i}+x_{j}} \cdot \frac{1}{8}\left(\frac{1}{\rho_{c, i}^{1 / 3}}+\frac{1}{\rho_{c, j}^{1 / 3}}\right)^{3}$

and

$T_{c, i j}=\beta_{T, i j} \gamma_{T, i j} \frac{x_{i}+x_{j}}{\beta_{T, i j}^{2} x_{i}+x_{j}}\left(T_{c, i} T_{c, j}\right)^{1 / 2}$

where $\rho_{c, i}$ and $T_{c, i}$ are the critical density and critical temperature of pure fluid $i, x_{i}$ is the mole fraction of component $i$ in the mixture, and $\beta_{v, i j}, \gamma_{v, i j}, \beta_{T, i j}$ and $\gamma_{T, i j}$ are binary interaction parameters (BIPs) between fluids $i$ and $j$. When few or no data are available, the BIPs can be set to unity. 
To describe experimental data more accurately, values less than or greater than unity can be used. When fitting BIPs to limited numbers of highly-accurate VLE or density data, it is typical to prioritise the parameters $\gamma_{v, i j}$ and $\gamma_{T, i j}$ and to introduce $\beta_{v, i j}$ and $\beta_{T, i j}$ only when justified by the data (Kunz et al., 2007). In cases where significant numbers of high-quality data are available, the mixture model can be extended via so-called 'departure functions' (Kunz et al., 2007). This technique was used by Akasaka (2013) to correlate data for the systems (R32 + R1234ze(E)) and (R32 + R1234yf) mentioned above to within their low uncertainty but was not required to achieve satisfactory fits in this work.

It worth to note that recently, Jaubert and coworkers added six fluorinated groups to the well-known Enhanced-PPR78 model, allowing for the estimation of the temperature-dependent binary interaction parameters $k_{i j}(T)$ in the PR EoS , thereby creating a predictive model that is able to describe the thermophysical properties of multi-component systems that contain a fluorocompound mixed with $\mathrm{CO}_{2}$ and/or an alkane. (Jean-Noël and Lucie, 1999; Jun-Wei et al., 2017).

The use of group-contribution approach allow for the prediction of the phase behavior and other thermophysical properties of not yet measured systems and can thus be extremely useful to design new processes and/or products. Jaubert and coworkers, in their proposed model, concluded that EPPR78 model can be safely used to design processes involving fluorocompounds or to implement a product-design approach aimed at identifying new-refrigerant mixtures. Their work also concluded the need for more VLE, VLLE, and mixture critical points to improve the current accuracy of predictive thermodynamic models.

\section{Results}

\subsection{Density}

Measured densities for seven near-equimolar binary refrigerant mixtures are reported in Tables S.1 to S.7 of the Supplementary Material. For each binary system, values of the liquid-phase density were obtained at nine temperatures between (252 and 294) K at four to eight pressures up to approximately $4 \mathrm{MPa}$. The relative uncertainties in the measured densities were $0.1 \%$ and $1 \%$ for the liquid and vapour phases, respectively.

\subsection{Vapour-Liquid Equilibria}

The measured values of saturation pressure $\left(p^{\text {sat }}\right)$ and the equilibrium liquid and vapour compositions $(x, y)$ for each binary refrigerant mixture at the experimental temperature $(T)$ are reported in Table 4.

Table 4. Measured VLE data for five binary refrigerant mixtures ${ }^{\mathrm{a}}$

\begin{tabular}{|c|c|c|c|c|c|c|}
\hline Mixture & $T / \mathrm{K}^{\mathrm{b}}$ & $p / \mathrm{MPa}^{\mathrm{c}}$ & $x_{1}$ & $u(x)$ & $y_{1}$ & $u(y)$ \\
\hline $\mathrm{R} 125(1)+\mathrm{R} 1234 \mathrm{ze}(\mathrm{E})(2)$ & 341.7 & 2.55 & 0.4787 & 0.0048 & 0.5820 & 0.0058 \\
\cline { 2 - 7 }$z_{1}=0.4963 \pm 0.0051$ & 293.5 & 0.81 & 0.4870 & 0.0049 & 0.6890 & 0.0069 \\
$\rho_{\text {overall }}=655 \pm 12 \mathrm{~kg} \cdot \mathrm{m}^{-3}$ & 274.5 & 0.46 & 0.4917 & 0.0049 & 0.7216 & 0.0072 \\
\hline $\mathrm{R} 134 \mathrm{a}(1)+\mathrm{R} 1234 \mathrm{ze}(\mathrm{E})(2)$ & 340.6 & 1.79 & 0.4930 & 0.0049 & 0.5375 & 0.0054 \\
$z_{1}=0.4930 \pm 0.0050$ & 293.5 & 0.52 & 0.4894 & 0.0049 & 0.5573 & 0.0056 \\
$\rho_{\text {overall }}=629 \pm 12 \mathrm{~kg} \cdot \mathrm{m}^{-3}$ & 273.5 & 0.28 & 0.4878 & 0.0049 & 0.5652 & 0.0057 \\
\cline { 2 - 7 } $\mathrm{R} 143 \mathrm{a}(1)+\mathrm{R} 1234 \mathrm{ze}(\mathrm{E})(2)$ & 340.4 & 2.33 & 0.4743 & 0.0047 & 0.5819 & 0.0058 \\
\cline { 2 - 7 }$z_{1}=0.4896 \pm 0.0045$ & 293.6 & 0.77 & 0.4810 & 0.0048 & 0.6616 & 0.0066 \\
$\rho_{\text {overall }}=683 \pm 12 \mathrm{~kg} \cdot \mathrm{m}^{-3}$ & 274.3 & 0.43 & 0.4799 & 0.0048 & 0.6871 & 0.0069 \\
\cline { 2 - 7 }
\end{tabular}




\begin{tabular}{|c|c|c|c|c|c|c|}
\hline R1234yf (1) + R1234ze(E) (2) & 341.7 & 1.82 & 0.6560 & 0.0066 & 0.6837 & 0.0068 \\
\cline { 2 - 7 }$z_{1}=0.6563 \pm 0.0048$ & 293.5 & 0.54 & 0.6557 & 0.0066 & 0.7127 & 0.0071 \\
\cline { 2 - 7 }$\rho_{\text {overall }}=629 \pm 12 \mathrm{~kg} \cdot \mathrm{m}^{-3}$ & 273.6 & 0.28 & 0.6555 & 0.0066 & 0.7251 & 0.0073 \\
\hline $\mathrm{R} 32(1)+\mathrm{R} 1234 \mathrm{yf}(2)$ & 340.9 & 4.22 & 0.7956 & 0.0080 & 0.8155 & 0.0082 \\
\cline { 2 - 7 }$z_{1}=0.7959 \pm 0.0050$ & 293.5 & 1.39 & 0.7943 & 0.0079 & 0.8578 & 0.0086 \\
$\rho_{\text {overall }}=767 \pm 14 \mathrm{~kg} \cdot \mathrm{m}^{-3}$ & 273.7 & 0.79 & 0.7936 & 0.0079 & 0.8628 & 0.0086 \\
\cline { 2 - 7 }
\end{tabular}

${ }^{\mathrm{a}} z_{1}=$ overall mole fraction of component 1 in prepared mixture, $\rho_{\text {overall }}=$ the overall filling density of the mixture for the isochoric VLE measurements. ${ }^{\mathrm{b}} u(T)=0.1 \mathrm{~K} .{ }^{\mathrm{c}} u(p)=0.02 \mathrm{MPa}$

\subsection{Isobaric Heat Capacities}

Pure liquid HFO refrigerants - R1234yf and R1234ze(E)

Isobaric heat capacities of liquid R1234yf and R1234ze(E) were measured at temperatures between (283.15 and 303.15) K (Table 5). The measurements of R1234ze(E) extend the available $c_{p}$ data to temperatures not previously studied.

$$
\text { ) }
$$

Table 5. Measured isobaric heat capacity data for pure liquid HFO refrigerants ${ }^{\mathrm{a}}$

\begin{tabular}{|c|c|c|c|c|c|c|c|}
\hline$T / \mathrm{K}$ & $p / \mathrm{MPa}$ & $c_{p} / \mathrm{kJ} \cdot \mathrm{K}^{-1} \cdot \mathrm{mol}^{-1}$ & $u\left(c_{p}\right) / \mathrm{kJ} \cdot \mathrm{K}^{-1} \cdot \mathrm{mol}^{-1}$ & $T / \mathrm{K}$ & $p / \mathrm{MPa}$ & $c_{p} / \mathrm{kJ} \cdot \mathrm{K}^{-1} \cdot \mathrm{mol}^{-1}$ & $u\left(c_{p}\right) / \mathrm{kJ} \cdot \mathrm{K}^{-1} \cdot \mathrm{mol}^{-1}$ \\
\hline \multicolumn{8}{|c|}{$R 1234 v f$} \\
\hline 283.2 & 0.67 & 0.152 & 0.0015 & 298.2 & 1.57 & 0.156 & 0.0016 \\
\hline 283.2 & 0.77 & 0.151 & 0.0015 & 283.2 & 2.07 & 0.150 & 0.0015 \\
\hline 288.2 & 0.77 & 0.152 & 0.0015 & 288.2 & 2.07 & 0.151 & 0.0015 \\
\hline 283.2 & 1.07 & 0.151 & 0.0015 & 293.2 & 2.07 & 0.155 & 0.0016 \\
\hline 288.2 & 1.07 & 0.152 & 0.0015 & 298.2 & 2.07 & 0.156 & 0.0016 \\
\hline 293.2 & 1.07 & 0.156 & 0.0016 & 283.2 & 3.07 & 0.149 & 0.0015 \\
\hline 298.2 & 1.07 & 0.157 & 0.0016 & 288.2 & 3.07 & 0.150 & 0.0015 \\
\hline 283.2 & 1.57 & 0.151 & 0.0015 & 293.2 & 3.07 & 0.154 & 0.0015 \\
\hline 288.2 & 1.57 & 0.151 & 0.0015 & 298.2 & 3.07 & 0.156 & 0.0016 \\
\hline 293.2 & 1.57 & 0.155 & 0.0016 & & & & \\
\hline \multicolumn{8}{|c|}{$R 1234 z e(E)$} \\
\hline 288.2 & 0.57 & 0.154 & 0.0015 & 288.2 & 2.07 & 0.155 & 0.0016 \\
\hline 288.2 & 0.77 & 0.155 & 0.0016 & 293.2 & 2.07 & 0.156 & 0.0016 \\
\hline 298.2 & 0.77 & 0.158 & 0.0016 & 298.2 & 2.07 & 0.158 & 0.0016 \\
\hline 288.2 & 1.07 & 0.155 & 0.0016 & 303.2 & 2.07 & 0.159 & 0.0016 \\
\hline 298.2 & 1.07 & 0.158 & 0.0016 & 288.2 & 3.07 & 0.154 & 0.0015 \\
\hline 288.2 & 1.57 & 0.154 & 0.0015 & 298.2 & 3.07 & 0.157 & 0.0016 \\
\hline 298.2 & 1.57 & 0.158 & 0.0016 & & & & \\
\hline
\end{tabular}

${ }^{a}$ Standard uncertainties in the temperature and pressure are $u(T)=0.15 \mathrm{~K}$ and $u(p)=0.01 \mathrm{MPa}$

For R1234yf, the relative deviations between the reference EOS due to Richter et al. (2011), our data and literature data are shown in Fig. 5. 


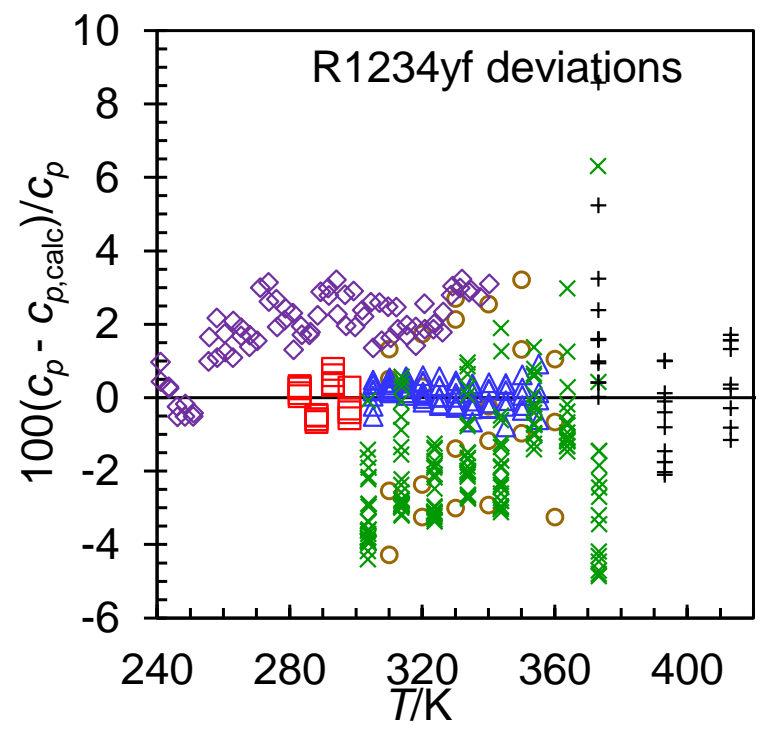

o Tanaka et al. (2014)

$\triangle$ Gao et al. (2014)

$\times$ Liu et al. (2017)

$\diamond$ Zhong et al. (2018)

+ Lukawaski et al. (2018)

$\square$ This work

Fig. 5. Relative deviations of literature and our measured isobaric heat capacities of liquid R1234yf from isobaric heat capacities calculated using the reference EOS for R1234yf EOS due to Richter et al. (2011) as implemented in NIST REFPROP 9.1. For the isochoric heat capacity $\left(c_{v}\right)$ data of Zhong et al. (2018) the ordinate is $100\left(c_{v}-c_{v, \text { calc }}\right) / c_{v}$ rather than $100\left(c_{p}-c_{p, \text { calc }}\right) / c_{p}$

Our data are in good accord with the EOS: the deviations are scattered about the zero line and are smaller than the estimated expanded $(k=2)$ uncertainty in the measurements of $2 \%$. The data of Gao et al. (2014) also exhibit low scatter. On the other hand, the data of Tanaka et al. (2010a), Liu et al. (2017) and Lukawaski et al (2017), as well as the isochoric heat capacity data of Zhong et al. (2018), deviate from the EOS by considerably larger amounts.

The relative deviations of our data and literature data for the isobaric heat capacity of R1234ze(E) calculated from the reference EOS due to Thol and Lemmon (2016) are shown in Fig. 6.

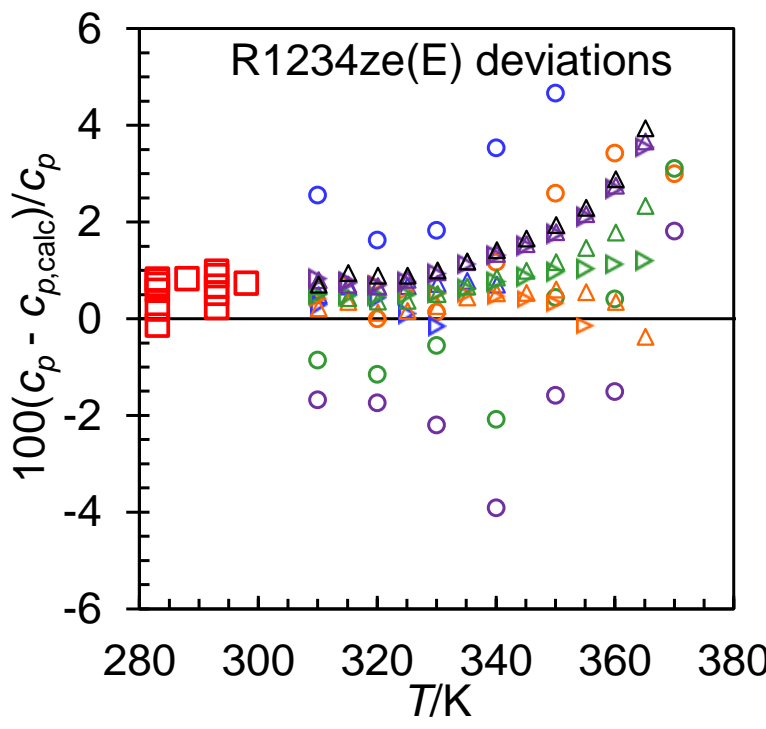

o Tanaka et al. 2010b, $2 \mathrm{MPa}$
o Tanaka et al. 2010b, $3 \mathrm{MPa}$
o Tanaka et al. 2010b, $4 \mathrm{MPa}$
o Tanaka et al. 2010b, $5 \mathrm{MPa}$
$\triangleright$ Gao et al. (2015), 1.56 MPa
$\triangle$ Gao et al. (2015), 2.03 MPa
$\triangleright$ Gao et al. (2015), 2.55 MPa
$\triangle$ Gao et al. (2015), 3.03 MPa
$\triangleright$ Gao et al. (2015), 3.61 MPa
$\triangle$ Gao et al. (2015), $4.07 \mathrm{MPa}$
$\triangleright$ Gao et al. (2015), $4.54 \mathrm{MPa}$
$\triangle$ Gao et al. (2015), $4.93 \mathrm{MPa}$
$\triangle$ Gao et al. (2015), $5.49 \mathrm{MPa}$
$\square$ This work

Fig. 6. Relative deviations of literature and our measured isobaric heat capacities of liquid $\mathrm{R} 1234 \mathrm{ze}(\mathrm{E})$ from isobaric heat capacities calculated using the reference EOS for R1234ze(E) due to Thol and Lemmon (2016) as implemented in NIST REFPROP 9.1. 
The deviations of the data measured in this work for R1234ze $(\mathrm{E})$ are smaller than the expanded $(k=$ 2) estimated uncertainty in the measurements of $2 \%$. As for R1234ze(E), the data of Gao et al. (2015) exhibit low scatter while the data of Tanaka et al. (2010b) appear to be less reliable in comparison. However, above approximately $340 \mathrm{~K}$, deviations between the EOS and the data of Gao et al. (2015) increase systematically with pressure, reaching $4 \%$ at $5.5 \mathrm{MPa}$. This perhaps suggests that the reference EOS for R1234ze(E) (Thol and Lemmon, 2016) could be improved by fitting to the these data.

\section{Isobaric heat capacities of binary liquid mixtures}

Measurements of the isobaric heat capacities of liquid binary mixtures of refrigerants near $p=2.0$ MPa are presented in Table 6.

Table 6. Measured isobaric heat capacity data for liquid binary refrigerant mixtures

\begin{tabular}{ccccccc}
\hline Component 1 & Component 2 & $x_{1}$ & $T / \mathrm{K}$ & $p / \mathrm{MPa}$ & $c_{p} / \mathrm{kJ} \cdot \mathrm{K}^{-1} \cdot \mathrm{mol}^{-1}$ & $u\left(c_{p}\right) / \mathrm{kJ} \cdot \mathrm{K}^{-1} \cdot \mathrm{mol}^{-1}$ \\
\hline R32 & R1234yf & 0.5022 & 283.2 & 2.07 & 0.121 & 0.0012 \\
R125 & R152a & 0.5000 & 293.2 & 2.07 & 0.137 & 0.0014 \\
R125 & R1234ze(E) & 0.5002 & 293.2 & 2.07 & 0.155 & 0.0016 \\
R134a & R1234ze(E) & 0.5000 & 313.2 & 2.07 & 0.155 & 0.0016 \\
R143a & R1234yf & 0.4959 & 293.2 & 2.07 & 0.144 & 0.0014 \\
R125 & R1234yf & 0.5001 & 293.2 & 2.07 & 0.155 & 0.0016 \\
R143a & R1234ze(E) & 0.4994 & 303.2 & 2.07 & 0.148 & 0.0015 \\
R1234yf & R1234ze(E) & 0.4994 & 303.2 & 2.07 & 0.160 & 0.0016 \\
\hline
\end{tabular}

${ }^{a}$ Standard uncertainties in the temperature, pressure and mole fraction are $u(T)=0.25 \mathrm{~K}$ and $u(p)=$ $0.01 \mathrm{MPa}, u\left(x_{1}\right)=0.001$ and the relative combined standard uncertainty in the isobaric heat capacity is $u_{\mathrm{r}}\left(c_{p}\right)=1 \%$.

\subsection{Parameter tuning results}

Tuned binary interaction parameters for the Helmholtz mixture model (Eqs. (3) and (4)) determined in this work are given in Table 7.

Table 7. Values of the thermodynamic binary interaction parameters tuned in this work and used by default in REFPROP 9.1

\begin{tabular}{|c|c|c|c|c|c|c|c|c|}
\hline & \multicolumn{4}{|c|}{ Tuned in this work } & \multicolumn{4}{|c|}{ Default in REFPROP 9.1} \\
\hline System & $\beta_{T, i j}$ & $\gamma_{T, i j}$ & $\beta_{v, i j}$ & $\gamma_{v, i j}$ & $\beta_{T, i j}$ & $\gamma_{T, i j}$ & $\beta_{v, i j}$ & $\gamma_{v, i j}$ \\
\hline $\mathrm{R} 134 \mathrm{a}+\mathrm{R} 1234 \mathrm{ze}(\mathrm{E})$ & 1.0 & 0.999 & 1.0 & 1.0 & $1.0^{\mathrm{a}}$ & $0.992^{\mathrm{a}}$ & $1.0^{\mathrm{a}}$ & $1.0^{\mathrm{a}}$ \\
\hline $\mathrm{R} 125$ + R1234ze(E) & 1.0 & 1.001 & 1.0 & 1.0 & $1.003^{\mathrm{a}}$ & $1.0071^{\mathrm{a}}$ & $1.0^{\mathrm{a}}$ & $1.0^{\mathrm{a}}$ \\
\hline R143a + R1234ze(E) & 1.0 & 1.0 & 1.0 & 1.012 & $1.0^{\mathrm{b}}$ & $0.99113^{\mathrm{b}}$ & $1.0^{\mathrm{b}}$ & $1.0027^{\mathrm{b}}$ \\
\hline R1234yf + R1234ze(E) & 1.0 & 1.0 & 1.0 & 1.0 & $1.0^{\mathrm{a}}$ & $0.987^{\mathrm{a}}$ & $1.0^{\mathrm{a}}$ & $1.0^{\mathrm{a}}$ \\
\hline $\mathrm{R} 125+\mathrm{R} 1234 \mathrm{yf}$ & 1.01 & 0.986 & 1.0 & 0.991 & 1.0 & 0.999 & 1.0 & 1.0 \\
\hline$R 143 a+R 1234 y f$ & 1.0 & 0.991 & 1.0 & 1.01 & $1.0^{\mathrm{b}}$ & $0.99144^{\mathrm{b}}$ & $1.0^{\mathrm{b}}$ & $1.0036^{\mathrm{b}}$ \\
\hline $\mathrm{R} 125+\mathrm{R} 152 \mathrm{a}$ & 1.0 & 1.0 & 1.0 & 1.01 & $1.0^{\mathrm{b}}$ & $0.98757^{b}$ & $1.0^{\mathrm{b}}$ & $1.002^{\mathrm{b}}$ \\
\hline
\end{tabular}

${ }^{\mathrm{a}}$ Parameter fitted to unpublished data

${ }^{\mathrm{b}}$ Mixture parameters were estimated from mixing rules (not based on tuning to data)

To avoid over-fitting the BIPs to data in a relatively narrow range of reduced temperature and reduced density, only one or two parameters were tuned in most cases. The starting point for fitting was to set all the BIPs equal to their standard values of unity. For the mixtures (R134a + R1234ze(E)), (R125+ 
$\mathrm{R} 1234 z \mathrm{E}(\mathrm{E}))$ and $(\mathrm{R} 1234 \mathrm{yf}+\mathrm{R} 1234 \mathrm{ze}(\mathrm{E}))$, little or no modification of the BIPs was required to achieve acceptable agreement with experimental data. It is worth to denote that no departure function was introduced for all mixtures. This is because the number of data and their range are not expansive enough to justify the additional model complexity.

RMS deviations were calculated by the following formula for the corresponding type of thermodynamic property

$$
\begin{gathered}
\operatorname{RMS}(\mathrm{VLE})=\left(\frac{1}{N} \sum_{n=1}^{N}\left(y_{1, n}-y_{1, \mathrm{calc}, n}\right)^{2}\right)^{\frac{1}{2}} \\
\operatorname{RMS}(\rho)=100\left(\frac{1}{N} \sum_{n=1}^{N}\left(\frac{\rho_{n}-\rho_{\text {calc }, n}}{\rho_{n}}\right)^{2}\right)^{\frac{1}{2}} \\
\operatorname{RMS}\left(c_{p}\right)=100\left(\frac{1}{N} \sum_{n=1}^{N}\left(\frac{c_{p, n}-c_{p, \text { calc }, n}}{c_{p, n}}\right)^{2}\right)^{\frac{1}{2}}
\end{gathered}
$$

where $y_{1}$ is the mole fraction of component 1 in the vapour at equilibrium. To calculate $y_{1}$ for our isochoric VLE measurements temperature-density flash calculations were utilised along the experimental isochore. For VLE data obtained from the literature, values of $y_{1}$ were calculated using a bubble-point pressure calculation. The statistical results of the tuning are summarised in Table 8. In cases where $N_{\text {tuned }}$ is zero, the data set was omitted from the tuning procedure. For some of the mixtures the higher uncertainty of the vapour density data meant that they were omitted from the tuning procedure.

Table 8. Sources of data for mixtures of HFOs and HFCs with the number of reported data, number

\begin{tabular}{|c|c|c|c|c|c|}
\hline Reference & Type & $N$ & RMS (default) & $N_{\text {tuned }}$ & RMS (tuned) \\
\hline \multicolumn{6}{|c|}{ R134a + R1234ze(E) } \\
\hline Zhang et al., 2017 & $\rho$ & 101 & 1.9 & 101 & 1.9 \\
\hline Raabe, 2014 & VLE & 3 & 0.011 & 0 & 0.020 \\
\hline This work & $\rho$ & 59 & 0.28 & 59 & 0.21 \\
\hline This work & $c_{p}$ & 1 & 1.2 & 0 & 0.97 \\
\hline This work & VLE & 3 & 0.016 & 3 & 0.016 \\
\hline \multicolumn{6}{|c|}{ R125 + R1234ze $(E)$} \\
\hline This work & $\rho$ & 44 & 0.26 & 43 & 0.08 \\
\hline This work & $c_{p}$ & 1 & 0.33 & 0 & 0.48 \\
\hline This work & VLE & 3 & 0.0090 & 3 & 0.0067 \\
\hline \multicolumn{6}{|c|}{ R143a + R1234ze $(E)$} \\
\hline This work & $\rho$ & 38 & 0.16 & 35 & 0.14 \\
\hline This work & $c_{p}$ & 1 & 0.33 & 0 & 0.017 \\
\hline This work & VLE & 3 & 0.045 & 3 & 0.044 \\
\hline \multicolumn{6}{|c|}{ R1234yf + R1234ze(E) } \\
\hline Higashi, 2016 & $\rho$ & 38 & $>5$ & 0 & $>5$ \\
\hline This work & $\rho$ & 37 & 0.48 & 33 & 0.14 \\
\hline
\end{tabular}
of data used for tuning in this work, and the RMS deviations between the default and tuned Helmholtz energy mixture models. 
This work $\begin{array}{ll}c_{p} & 1\end{array}$

0.63

0.95

This work

VLE 3

0.010

0

0.00084

Kamiaka et al., 2013

VLE $\quad 56$ R125 + R1234yf

This work

This work

$\rho \quad 40$

0.021

0.011

$c_{p}$

0.18

56

0.065

$1 \quad 0.87$

36

$0 \quad 1.3$

Hu et al., 2013

This work

This work

$\begin{array}{ll}\text { VLE } & 35 \\ \rho & 36 \\ c_{p} & 1\end{array}$

R143a + R1234yf

0.0053

0.0051

0.33

0.021

1

0.018

\section{5}

0.025

Nishiumi et al., 1997

VLE 87

R125 + R152a

33

0

.

Lim et al., 2000

VLE 6

0.028

87

0.023

This work

$\rho \quad 53$

0.026

6

52

0.34

Improvements in the prediction of density after tuning were most significant for the mixtures (R134a + R1234ze(E)), (R143a + R1234yf)), (R1234yf + R1234ze(E)) and (R125 + R1234yf) (Fig. 7) as well as $(\mathrm{R} 125+\mathrm{R} 1234 \mathrm{ze}(\mathrm{E}))$. In fact the absolute relative deviations between the tuned EOS and all of the measured liquid densities for the (R134a + R1234ze(E)) and (R143a + R1234yf) binary mixtures were less than $0.08 \%$ and $0.04 \%$, respectively, which are within the experimental uncertainty $(0.1 \%)$. One of the sources of density data from the literature were found to be unsuitable for tuning the Helmholtz mixing BIPs. The isochoric data sets of Higashi (2016) for (R1234yf + $\mathrm{R} 1234 \mathrm{ze}(\mathrm{E}))$ at $(200,480$ and 700$) \mathrm{kg} \cdot \mathrm{m}^{-3}$ showed large systematic deviations from the model. Accordingly, Higashi's data were excluded from tuning.
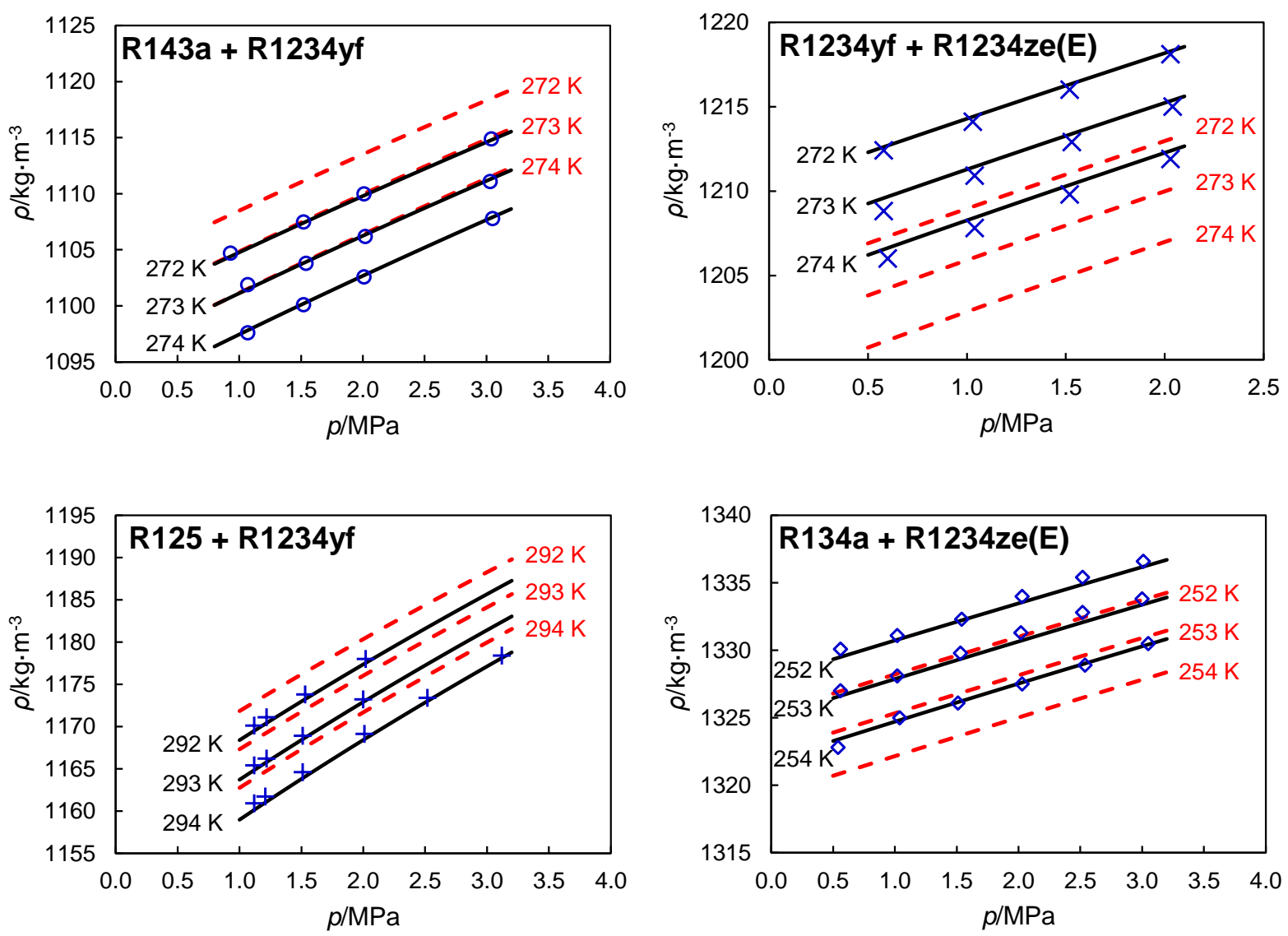
Fig. 7. Examples of the improvement in the calculated density of the mixtures: symbols, measured data; dashed lines, default Helmholtz energy mixture model; solid lines, tuned Helmholtz energy mixture model

Improvements to the calculation of VLE are illustrated in Fig. 8. The most significant improvement was for the (R1234yf + R1234ze(E)) binary mixture where the RMS deviation in the calculated vapour phase compositions decreased by a factor of 12 (refer Table 8). Only small improvements could be achieved for other systems such as (R125 + R1234ze(E)) and (R143a + R1234ze(E)). For $(\mathrm{R} 32+\mathrm{R} 1234 \mathrm{yf})$, there is good agreement between our data and the relatively large number of available literature VLE data (Akasaka et al, 2013; Kamiaka, 2013) which were used for the development of the default model for $(\mathrm{R} 32+\mathrm{R} 1234 \mathrm{yf})$. For this reason, no attempt was made to improve the EOS for (R32 + R1234yf).
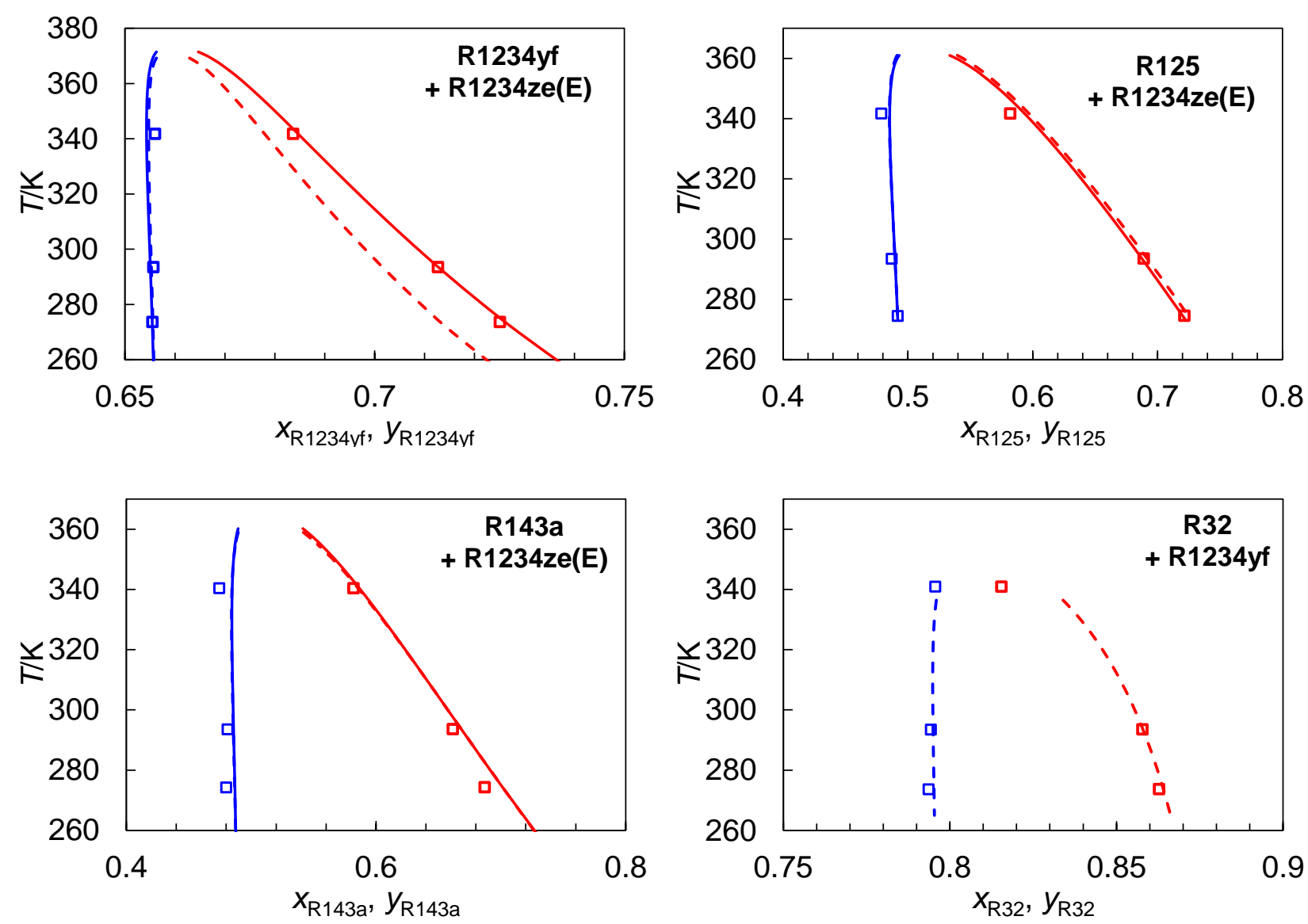

Fig. 8. Examples of improvement in the calculation of VLE data. The lines were calculated using a temperature-density flash calculation and represent the experimental isochore based on the fixed overall density of the mixture sample that was measured. Symbols, measured data; dashed lines, calculated dew and bubble curves with the default Helmholtz energy mixture model; solid lines, calculated dew and bubble curves using tuned Helmholtz energy mixture model. For (R32 + R1234yf) tuning was not performed as the significant number of existing literature data meant that previous tuning of the model was adequate. Thus only a comparison to this default model of Akasaka (2013) is illustrated. 
Improvement to the calculation of the isobaric heat capacity was not possible, as the RMS deviations of the isobaric heat capacities calculated using the default REFPROP 9.1 were less than or approximately equal to the experimental uncertainty in all cases.

\section{Conclusions}

In this paper we present 340 new measurements of thermophysical properties in binary mixtures of $\mathrm{HFC}+\mathrm{HFO}$, namely R1234yf or R1234ze(E). Some of these measurements constitute the first available data for a mixture of these two components for a particular property. In summary, we measured:

1. Liquid and vapour densities of eight equimolar mixtures: R1234ze $(E)+[R 125, R 134 a$, R143a, R1234yf]; R1234yf + [R125, R134a, R143a]; and (R125 + R152a) measured by vibrating tube densimetry at temperatures between (252 and 294) $\mathrm{K}$ and pressures from (0.5 to 4.2) $\mathrm{MPa}$

2. Vapour-liquid equilibria (VLE) of five equimolar binary mixtures: R1234ze(E) + [R125, R134a, R143a, R1234yf] and (R32 + R1234yf) measured by the analytic method (sampling with gas chromatograph analysis) at temperatures of $(273,293$ and 343) $\mathrm{K}$ and pressures from (0.3 to 2.6) $\mathrm{MPa}$.

3. Liquid heat capacities of seven equimolar binary mixtures: R1234ze(E) $+[R 125, R 134 a$, R143a, R1234yf]; R1234yf + [R125, R143a]; and (R125 + R152a) and pure R1234yf and $\mathrm{R} 1234 z e(\mathrm{E})$ by differential scanning calorimetry at temperatures between (283 and 313) $\mathrm{K}$ and pressures between (0.6 and 3.1) $\mathrm{MPa}$

Helmholtz EOS BIPs were tuned both to the data that we collected in this work as well as literature data for VLE, density, and heat capacities to improve the prediction of these thermodynamic properties. The tuning significantly improved the prediction of thermodynamic properties, particularly the densities for the (R134a + R1234ze(E)), (R143a + R1234yf)), (R125 + R1234yf) and $(\mathrm{R} 125+\mathrm{R} 1234 \mathrm{ze}(\mathrm{E}))$ binaries and both the densities and VLE for the (R1234yf + R1234ze(E)) binary. With these improved models it should be possible to more reliably simulate refrigeration processes involving these mixtures.

Further improvements to the prediction of the thermodynamic properties of mixtures containing $\mathrm{R} 1234 z e(\mathrm{E})$ could be made if an improved equation of state for the pure component is developed. Deviations of the calculated isobaric heat capacity from our measurements for pure R1234yf and $\mathrm{R} 1234 \mathrm{ze}(\mathrm{E})$ suggest that the performance of the reference equation of state for R1234yf may be better than for R1234ze(E), which further suggests the potential to improve upon the existing reference EOS for R1234ze(E).

The research conducted in the present study has enabled MHI to design new, more environmentallyfriendly air-conditioning systems. As a result of the new data and improved thermodynamic models produced, MHI were able to reduce the margin they applied when determining the surface area requirements of heat exchangers from $30 \%$ to $10 \%$. This is a real case illustrating how an accurate and improved thermodynamic models are needed in the design and operation of industrial processes.

\section{Acknowledgements}

Funding: This work was supported by Mitsubishi Heavy Industries, Ltd. 


\section{References}

Akasaka, R. Vapor-Liquid Equilibrium Modeling for Mixtures of HFC-32 + Isobutane and HFC-32 + HFO-1234ze(E). International Journal of Air-Conditioning and Refrigeration 2011, 19, 93 97.

Akasaka, R. Thermodynamic property models for the difluoromethane (R-32) + trans-1,3,3,3tetrafluoroproppene $(\mathrm{R}-1234 \mathrm{ze}(\mathrm{E}))$ and difluoromethane + 2,3,3,3-tetrafluoropropene (R1234yf) mixtures, Fluid Phase Equilib. 2013, 358, 98-104.

Akasaka, R.; Tanaka, K.; Higashi, Y. Measurements of Saturated Densities and Critical Parameters for the Binary Mixture of 2,3,3,3-Tetrafluoropropene (R-1234yf) + Difluoromethane (R-32). Int. J. Refrig. 2013, 36, 1341-1346.

Dang, Y.; Kim, H. S.; Dang, C.; Hihara, E. Measurement of Vapor Viscosity of R1234yf and its Binary Mixtures with R32, R125. Int. J. Refrig. 2015, 58, 131-136.

Gao, N.; Jiang, Y.; Wu, J.; He, Y.; Chen, G. Measurements of the Isobaric Heat Capacity of R1234yf in Liquid Phase at Temperatures from $305 \mathrm{~K}$ to $355 \mathrm{~K}$ and Pressures up to $5 \mathrm{MPa}$. Fluid Phase Equilib. 2014, 376, 64-68.

Gao, N.; Chen, G.; Li, R.; Wang, Y.; He, Y.; Yang, B. Measurements of the Isobaric Heat Capacity of Pressurized Liquid Trans-1,3,3,3-Tetrafluoropropene [R1234ze(E)] by Scanning Calorimetry. J. Therm. Anal. Calorim. 2015, 122, 1469-1476.

Higashi, Y. Measurements of Thermodynamic Properties for the 50 Mass\% R1234yf + 50 Mass\% R1234ze(E) Blend. Sci. Technol. Built Environ. 2016, 22, 1185-1190.

Hu, P.; Chen, L.-X.; Chen, Z.-S. Vapor-Liquid Equilibria for the 1,1,1,2-Tetrafluoroethane (HFC134a) + 1,1,1,2,3,3,3-Heptafluoropropane (HFC-227ea) and 1,1,1-Trifluoroethane (HFC143a) + 2,3,3,3-Tetrafluoroprop-1-ene (HFO-1234yf) Systems. Fluid Phase Equilib. 2013, 360, 293-297.

Hu, X.; Yang, T.; Meng, X.; Bi, S.; Wu, J. Vapor Liquid Equilibrium Measurements for Difluoromethane (R32) +2,3,3,3-Tetrafluoroprop-1-ene (R1234yf) and Fluoroethane (R161) + 2,3,3,3-Tetrafluoroprop-1-ene (R1234yf). Fluid Phase Equilib. 2017, 438, 10-17.

Hughes, T. J.; Syed, T.; Graham, B. F.; Marsh, K. N.; May, E. F. Heat Capacities and Low Temperature Thermal Transitions of 1-Hexyl and 1-Octyl-3-Methylimidazolium Bis(trifluoromethylsulfonyl)amide. J. Chem. Eng. Data 2011, 56, 2153-2159.

Hughes, T. J.; Kandil, M. E.; Graham, B. F.; May, E. F. Simulating the Capture of $\mathrm{CO}_{2}$ from Natural Gas: New Data and Improved Models for Methane + Carbon Dioxide + Methanol. Int. J. Greenhouse Gas Control 2014, 31, 121-127.

Hughes, T. J.; Kandil, M. E.; Graham, B. F.; Marsh, K. N.; Huang, S. H.; May, E. F. Phase Equilibrium Measurements of (Methane + Benzene) and (Methane + Methylbenzene) at Temperatures from (188 to 348) $\mathrm{K}$ and Pressures to $13 \mathrm{MPa}$. J. Chem. Thermodyn. 2015, 85, 141-147.

Hughes, T. J.; Guo, J. Y.; Baker, C. J.; Rowland, D.; Graham, B. F.; Marsh, K. N.; Huang, S. H.; May, E. F. High pressure multi-component vapor-liquid equilibrium data and model predictions for the LNG industry. J. Chem. Thermodyn. 2017, 113, 81-90.

Jia, T.; Bi, S.; Hu, X.; Meng, X.; Wu, J. Volumetric Properties of Binary Mixtures of \{Difluoromethane (R32) + Trans-1,3,3,3-Tetrafluoropropene (R1234ze(E)) \} at Temperatures from $283.15 \mathrm{~K}$ to $363.15 \mathrm{~K}$ and Pressures up to $100 \mathrm{MPa}$. J. Chem. Thermodyn. 2016, 101, 54-63. 
Jean-Noël Jaubert* and Lucie Coniglio. The Group Contribution Concept: A Useful Tool To Correlate Binary Systems and To Predict the Phase Behavior of Multicomponent Systems Involving Supercritical $\mathrm{CO}_{2}$ and Fatty Acids. Ind. Eng. Chem. Res. 1999, 38 (12), 5011-5018

Jun-Wei Qian, Romain Privat, Jean-Noël Jaubert, Christophe Coquelet, Deresh Ramjugernath. Fluidphase-equilibrium prediction of fluorocompound-containing binary systems with the predictive E-PPR78 model. Int. J. Refrig. 2017, 73, 65-90, 0140-7007

Kamiaka, T.; Dang, C.; Hihara, E. Vapor-Liquid Equilibrium Measurements for Binary Mixtures of R1234yf with R32, R125, and R134a. Int. J. Refrig. 2013, 36, 965-971.

Kandil, M. E.; May, E. F.; Graham, B. F.; Marsh, K. N.; Trebble, M. A.; Trengove, R. D.; Huang, S. H. Vapor-Liquid Equilibria Measurements of Methane +2 -Methylpropane (Isobutane) at Temperatures from (150 to 250) K and Pressures to 9 MPa. J. Chem. Eng. Data 2010, 55, $2725-2731$.

Kandil, M. E.; Thoma, M. J.; Syed, T.; Guo, J.; Graham, B. F.; Marsh, K. N.; Huang, S. H.; May, E. F. Vapor-Liquid Equilibria Measurements of the Methane + Pentane and Methane + Hexane Systems at Temperatures from (173 to 330) K and Pressures to $14 \mathrm{MPa}$. J. Chem. Eng. Data 2011, 56, 4301-4309.

Kunz, O.; Klimeck, R.; Wagner, W.; Jaeschke, M. GERG Technical Monograph 15, 2007.

Kunz, O.; Wagner, W. J. Chem. Eng. Data 2012, 57, 3032-3091

Kobayashi, K.; Tanaka, K.; Higashi, Y. P $\rho T x$ Property Measurements of Binary HFO-1234ze(E)+ HFC-32 Refrigerant Mixtures. Trans. of the JSRAE 2011, 28, 415-426.

Lemmon, E. W.; Jacobsen, R. T. An International Standard Formulation for the Thermodynamic Properties of 1,1,1-Trifluoroethane (HFC-143a) for Temperatures From 161 to $450 \mathrm{~K}$ and Pressures to $50 \mathrm{MPa}$. J. Phys. Chem. Ref. Data 2000, 29, 521-552.

Lemmon, E. W.; Jacobsen, R. T. A New Functional Form and New Fitting Techniques for Equations of State with Application to Pentafluoroethane (HFC-125). J. Phys. Chem. Ref. Data 2005, 34, 69-108.

Lemmon, E. W.; Huber, M. L.; McLinden, M. O. NIST Standard Reference Database 23: Reference Fluid Thermodynamic and Transport Properties-REFPROP, 9.1; National Institute of Standards and Technology: Gaithersburg, MD, 2013.

Lim, J. S.; Park, J.-Y.; Lee, B.-G. Vapor-Liquid Equilibria of CFC Alternative Refrigerant Mixtures: Trifluoromethane (HFC-23)+Difluoromethane (HFC-32), Trifluoromethane (HFC23)+Pentafluoroethane (HFC-125), and Pentafluoroethane (HFC-125)+1,1-Difluoroethane (HFC-152a). Int. J. Thermophys. 2000, 21, 1339-1349.

Liu, Y.; Zhao, X.; Lv, S.; He, H. Isobaric Heat Capacity Measurements for R1234yf from 303 to 373 K and Pressures up to $12 \mathrm{MPa}$. J. Chem. Eng. Data 2017, 62, 1119-1124.

Lukawski, M.Z., Ishmael, M.P.E., Tester, J.W. Isobaric Heat Capacity Measurements of Supercritical R1234yf. J. Chem. Eng. Data 2018, 63, 463-469.

May, E. F.; Tay, W. J.; Nania, M.; Aleji, A.; Al-Ghafri, S.; Martin Trusler, J. P. Physical Apparatus Parameters and Model for Vibrating Tube Densimeters at Pressures to $140 \mathrm{MPa}$ and Temperatures to 473 K. Rev. Sci. Instrum. 2014, 85, 095111.

May, E. F.; Guo, J. Y.; Oakley, J. H.; Hughes, T. J.; Graham, B. F.; Marsh, K. N.; Huang, S. H. Reference Quality Vapor-Liquid Equilibrium Data for the Binary Systems Methane + Ethane, + Propane, + Butane, and + 2-Methylpropane, at Temperatures from (203 to 273) K and Pressures to $9 \mathrm{MPa}$. J. Chem. Eng. Data 2015, 60, 3606-3620.

Nishiumi, H.; Akita, H.; Akiyama, S. High pressure vapor-liquid equilibria for the HFC125-HFC152a system. Korean J. Chem. Eng. 1997, 14, 359-364. 
Oakley, J. H.; Hughes, T. J.; Graham, B. F.; Marsh, K. N.; May, E. F. Determination of melting temperatures in hydrocarbon mixtures by differential scanning calorimetry. J. Chem. Thermodyn. 2017, 108, 59-70.

Outcalt, S. L.; McLinden, M. O. A Modified Benedict-Webb-Rubin Equation of State for the Thermodynamic Properties of R152a (1,1 - difluoroethane). J. Phys. Chem. Ref. Data 1996, 25, 605-636.

Raabe, G. Molecular Dynamics Studies on Liquid-Phase Dynamics and Structures of Four Different Fluoropropenes and Their Binary Mixtures with R-32 and $\mathrm{CO}_{2}$. The Journal of Physical Chemistry B 2014, 118, 240-254.

Richter, M.; McLinden, M. O.; Lemmon, E. W. Thermodynamic Properties of 2,3,3,3Tetrafluoroprop-1-ene (R1234yf): Vapor Pressure and $p-\rho-T$ Measurements and an Equation of State. J. Chem. Eng. Data 2011, 56, 3254-3264.

Rowland, D.; Hughes, T. J.; May, E. F. J. Chem. Thermodyn. 2016, 97, $206-213$.

Syed, T. H.; Hughes, T. J.; Marsh, K. N.; May, E. F. Isobaric Heat Capacity Measurements of Liquid Methane, Ethane, and Propane by Differential Scanning Calorimetry at High Pressures and Low Temperatures. J. Chem. Eng. Data 2012, 57, 3573-3580.

Syed, T. H.; Hughes, T. J.; Marsh, K. N.; May, E. F. Isobaric Heat Capacity Measurements of Liquid Methane + Propane, Methane + Butane, and a Mixed Refrigerant by Differential Scanning Calorimetry at High Pressures and Low Temperatures. J. Chem. Eng. Data 2014, 59, 968974.

Syed, T. H.; Hughes, T. J.; May, E. F. Enthalpy of Vaporization Measurements of Liquid Methane, Ethane, and Methane + Ethane by Differential Scanning Calorimetry at Low Temperatures and High Pressures. J. Chem. Eng. Data 2017, 62, 2253-2260.

Tanaka, K.; Higashi, Y.; Akasaka, R. Measurements of the Isobaric Specific Heat Capacity and Density for HFO-1234yf in the Liquid State. J. Chem. Eng. Data 2010a, 55, 901-903.

Tanaka, K.; Takahashi, G.; Higashi, Y. Measurements of the Isobaric Specific Heat Capacities for trans-1,3,3,3-Tetrafluoropropene (HFO-1234ze(E)) in the Liquid Phase. J. Chem. Eng. Data 2010b, 55, 2267-2270.

Tanaka, K.; Akasaka, R.; Higashi, Y. Measurements of Density and Isobaric Specific Heat Capacity for HFO-1234ze(E)+HFC-32 Mixtures. Trans. of the JSRAE 2011, 28, 427-434.

Thol, M.; Lemmon, E. W. Equation of State for the Thermodynamic Properties of trans-1,3,3,3Tetrafluoropropene [R-1234ze(E)]. Int. J. Thermophys. 2016, 37, 1-16.

Tillner-Roth, R.; Baehr, H. D. An International Standard Formulation for the Thermodynamic Properties of 1,1,1,2 - Tetrafluoroethane (HFC - 134a) for Temperatures from $170 \mathrm{~K}$ to 455 K and Pressures up to 70 MPa. J. Phys. Chem. Ref. Data 1994, 23, 657-729.

Tillner-Roth, R.; Yokozeki, A. An International Standard Equation of State for Difluoromethane (R32) for Temperatures from the Triple Point at $136.34 \mathrm{~K}$ to $435 \mathrm{~K}$ and Pressures up to $70 \mathrm{MPa}$. J. Phys. Chem. Ref. Data 1997, 26, 1273-1328.

Zhang, H.; Dong, X.; Zhong, Q.; Li, H.; Gong, M.; Shen, J.; Wu, J. Investigation of $p \rho T x$ Properties for R1234ze(E) + R134a Mixtures in the Gas Phase. Int. J. Refrig. 2017, 73, 144-153.

Zhong, Q., Dong, X., Zhao, Y., Wang, J., Zhang, H., Li, H., Guo, H., Shen, J., Gong, M. Adiabatic Calorimeter for Isochoric Specific Heat Capacity Measurements and Experimental Data of Compressed Liquid R1234yf. J. Chem. Thermodyn. 2018, 125, 86-92. 